\title{
Technical modification for composite grafts in myocardial revascularization surgery
}

\author{
Modificação técnica para enxertos combinados em operação de revascularização do miocárdio
}

Paulo CHACCUR, Josué V. Castro NEVES, Eliévia Maria Oliveira ESCÓSSIO, Luís Fernando PORTUGAL, José Carlos MUSSI

RBCCV 44205-603

\section{Abstract}

Objective: In the last decade, the coronary artery bypass grafts (CABG) with arterial grafting had been remarkable, mainly the combined ones in $\mathrm{Y}$ or $\mathrm{T}$ form, which start from the left internal thoracic artery (LITA). Elaborating this kind of grafting, we identified a certain worry related to the anastomoses of the radial artery in LITA, principally when realized in $\mathrm{T}$, since any small traction, angulations or spasms of the radial artery might impaired the flow of the distal anastomoses of LITA to the anterior interventricular artery.

Method: We modified the combined graft technique, by making anastomoses of the radial artery to the anterior interventricular artery, and, consequently the LITA is sewed above the anastomoses of the radial artery to the anterior interventricular artery, favoring therefore, the revascularization of the anterior interventricular artery with the LITA, transforming the radial artery into almost an extension of the LITA to the remaining branches of the left coronary artery.

Conclusions: This technical modification for these composite grafts is simple, safer and effective, and it will enable a larger number of surgeons to routinelyuse composite grafts in coronary artery bypass grafting.

Descriptors: coronary artery bypass grafting, methods. Mammary arteries, surgery. Radial artery.

\section{Resumo}

Objetivo: A operação de revascularização do miocárdio com enxertos arteriais tem tido grande destaque nesta última década, e principalmente, os enxertos combinados em forma de $Y$ ou $T$ a partir da artéria torácica interna esquerda (ATIE). Trabalhando com este tipo de enxerto, identificamos alguma preocupação quanto à anastomose da artéria radial na ATIE, principalmente quando é realizada em $\mathrm{T}$, podendo qualquer pequena tração, angulação ou mesmo espasmo da artéria radial, prejudicar o fluxo na porção distal da ATIE para a artéria interventricular anterior.

Método: Modificamos a técnica do enxerto combinado, fazendo a anastomose da artéria radial na artéria interventricular anterior e, a seguir, a ATIE foi suturada sobre a anastomose da artéria radial na artéria interventricular anterior, privilegiando, portanto, a revascularização da artéria interventricular anterior com a ATIE, transformando a artéria radial em quase um prolongamento da ATIE para os demais ramos da artéria coronária esquerda.

Conclusões: Esta modificação técnica para estes enxertos combinados é simples, mais segura e efetiva, e possibilitará que um maior número de cirurgiões passe a utilizar rotineiramente os enxertos combinados em suas operações de revascularização do miocárdio.

Descritores: Revascularização miocárdica, métodos. Artérias mamárias, cirurgia. Artéria radial.

Work performed in the Dante Pazzanese Heart Institute and Hospital do Coração. São Paulo, SP, Brazil.

Correspondence address: Paulo Chaccur. Praça Irmãos Karman 111 CEP: 01252-000. São Paulo São Paulo, Brazil.

e-mail: chaccur@cardiol.br 


\section{INTRODUCTION}

Coronary artery bypass grafting using the left internal thoracic artery (LITA) for the anterior interventricular artery and saphenous vein bypasses has given good results over the medium-term $[1,2]$, but there are limitations due to degeneration of these venous grafts. An improved eventfree survival after coronary artery bypass grafting has been obtained with the use of additional arterial grafts as was demonstrated by some investigators $[3,4]$ but this was questioned by others [5,6]. Recently, LYTTLE et al. [7] demonstrated the impact of the utilization of two internal thoracic arteries on re-intervention and mortality. Critics of this conduct question which coronary artery the other internal thoracic artery (ITA) should be used for and the number of revascularized areas with non-arterial grafts there should be.

Total arterial revascularization of the left coronary artery can be achieved with the use of a combination of grafts, both LITA and other arterial grafts. One of the techniques to perform this composite arterial grafting is by the anastomoses of the radial artery in a ' $\mathrm{T}$ ' or ' $\mathrm{Y}$ ' shape into the LITA [8-14]. This procedure brings about certain concerns in relation to its execution, mainly in cases in which the LITA has a reduced caliber that might interfere with the distal flow of the LITA to the anterior interventricular artery.

ROYSE et al. [15] measured the flow in the ITA near to Yshaped grafts and observed a combined free flow of $173+$ $16 \mathrm{ml} / \mathrm{min}$. When each of the distal branches were alternatively occluded, the flow was $114+15 \mathrm{ml} / \mathrm{min}$ and 99 $+9 \mathrm{ml} / \mathrm{min}$ respectively for the radial artery and LITA demonstrating that the ITA has capacity to adapt to the coronary vascular flow. They also evidenced that the flow through the radial artery was similar to that of the ITA, in spite of the difference in caliber between these grafts when they were not connected to the coronary circulation.

Our proposal for composite grafts was not to perform anastomoses on the LITA but to perform anastomoses of the radial artery on the anterior interventricular artery, thereby directly irrigating the anterior interventricular artery and also the oblique and marginal branches of the circumflex artery. This technique would reduce the technical risks of the composite graft and reduce the possibility of compromising the flow to the anterior interventricular artery, thus making the radial artery as if it were an extension of and not just a branch of the ITA.

\section{METHOD}

From January 1999 to December 2001, thirty-one patients were submitted to surgical coronary artery bypass grafting using composite arterial grafts. Twenty-three (74.2\%) were male. Commitment from coronary arterial disease affecting three arteries was evidenced in $90.3 \%$ of the patients and $19.4 \%$ presented with left coronary branch lesions. All patients were operated on under cardiopulmonary bypass, hypothermia of $32^{\circ} \mathrm{C}$ and intermittent clamping of the aorta. First end-to-side anastomose of the radial artery to the last branch of the circumflex artery was performed. Following this, side-to-side (diamond-shaped) anastomose was performed on the marginal and oblique branches and finally end-to-side anastomose was effected in the anterior interventricular artery. Subsequently, anastomose of the LITA on the radial artery was performed above the anastomosis of the radial and the anterior interventricular arteries (Figures 1 and 2).

To complete the coronary artery bypass, when required for the right coronary artery, venous grafts and right internal thoracic arteries were used in 14 and 4 patients respectively. In $19.4 \%$ of the patients, associated procedures were effected among which were arterioplasties, endarterectomies and right coronary ostioplasty.

Figure 1 shows the aspect of the composite graft of the internal thoracic artery with the radial artery, which was anastomosed in the anterior interventricular artery, oblique artery, marginal 1 artery and marginal 2 artery, sequentially.

Figure 2 shows details of the anastomosis of the LITA over the radial artery. Observe the superimposed anastomosis on the anterior interventricular artery.

This analysis was prospective during hospitalization and $6(19.3 \%)$ of the patients consented to a second investigation and were submitted to a cinecoronariography on either the fifth, sixth or seventh day of hospitalization.

\section{RESULTS}

The mean age was 49.9 years and the number of revascularized vessels using composite grafts was, on average, 3.2. The cardiopulmonary bypass and anoxia times were, on average, 92.6 and 72.3 minutes, respectively.

Two patients presented with low cardiac output in the

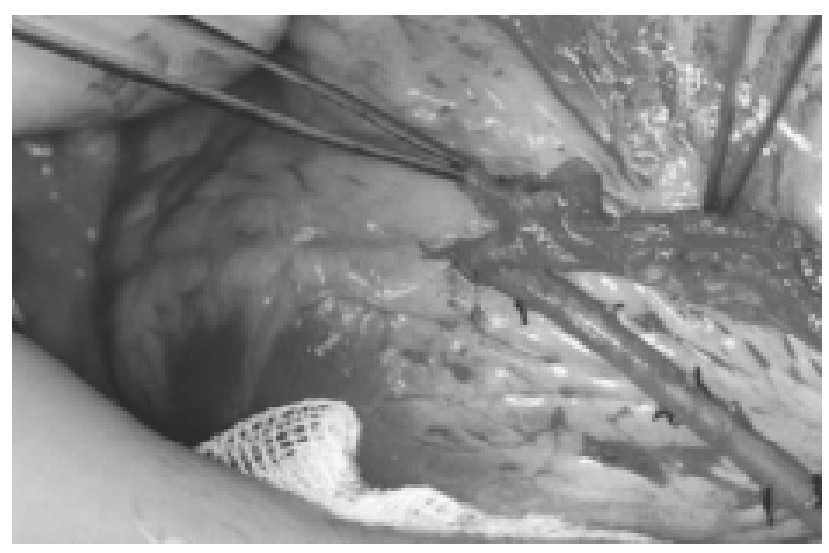

Fig. 1 - Modified composite graft - LITA radial sequential. 


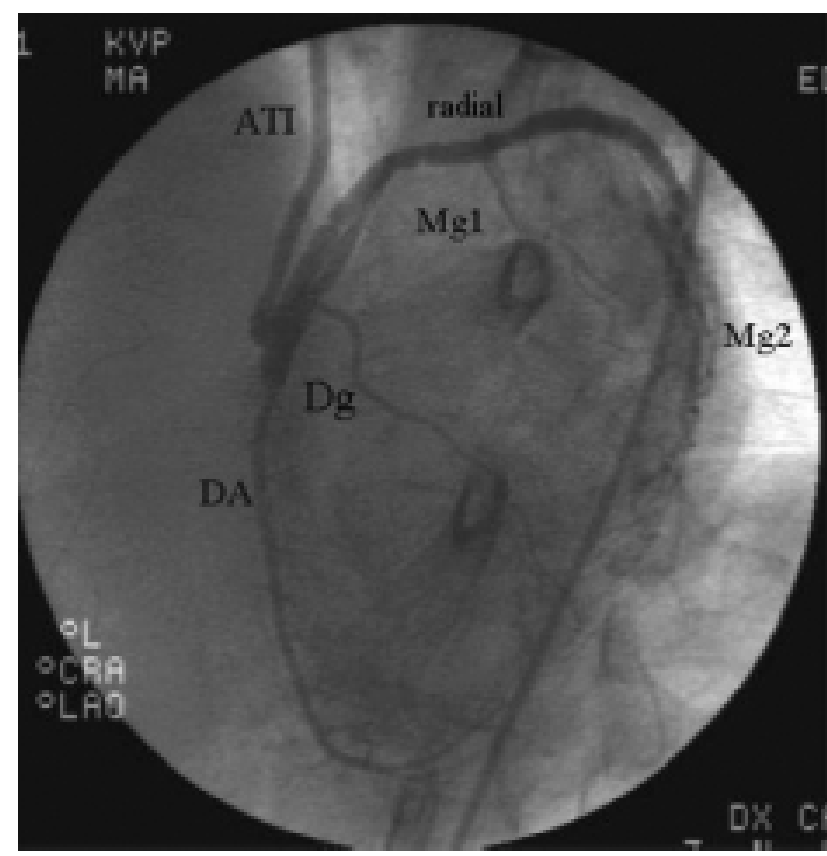

Fig. 4 - Detail of the anastomoses of the LITA in the radial artery, and the radial artery over the anterior interventricular artery.

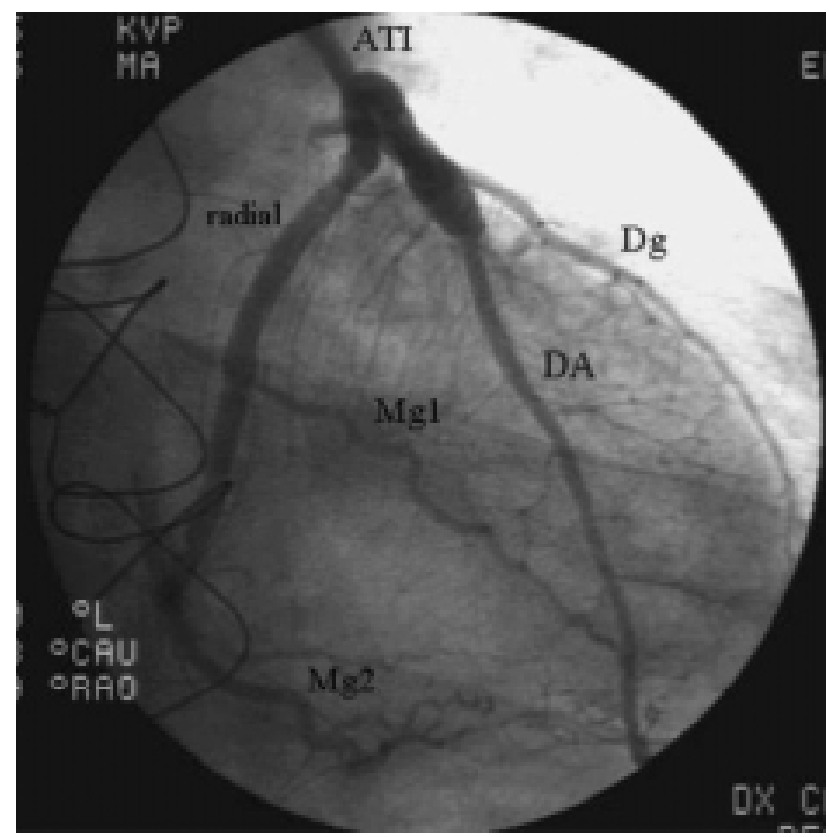

Fig. 5 - Total revascularization of the left coronary artery with a composite graft.

The second post-operative angiographic study identified the pervious nature of the composite grafts, identifying spasms of the radial artery in one patient and low flow in another, due to the competitive flow through the native channels.

Figures 3, 4 and 5 relating to the coronary cineangiographic studies immediately after surgery,
Fig. 3 - LITA irrigating the anterior interventricular, oblique and 1 \& 2 marginal arteries. 
demonstrate the LITA with a very good caliber, irrigating the left coronary artery branches, with evidence of the filling of the anterior interventricular, oblique and 1 and 2 marginal arteries.

Figure 4 illustrates anastomosis of the LITA on the radial artery and the radial artery on the anterior interventricular artery.

Figure 6 shows the left ventricle in systole, with a good ventricular function without signs of alterations of segmental contractility.

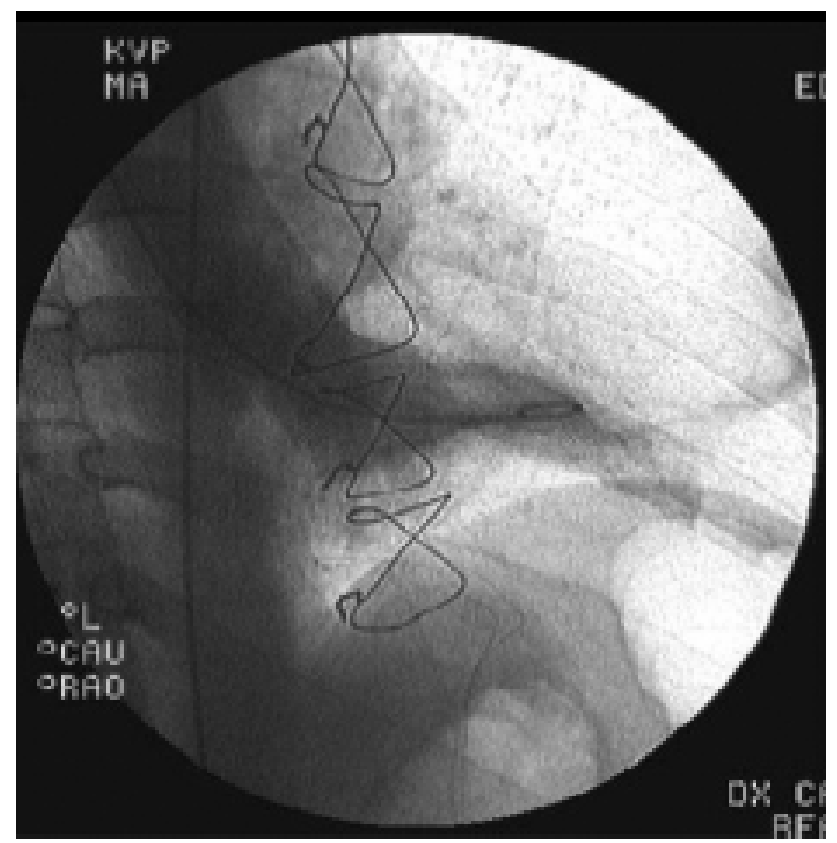

Fig. 6 - Left ventriculography in systole with normal ventricular function.

\section{COMMENTS}

Increasing use of coronary artery bypass grafting employing arterial grafts has been evidenced, albeit slowly, and composite grafts (using the radial arterial), which can facilitate this type of revascularization are not attractive yet to the majority of surgeons. This is due to some technical concerns about Y- and T-shaped anastomosis of the radial artery with the ITA, which can compromise the results of the surgery. The long-term outcomes of these patients treated with this modified graft will be reported in the future.

The employed technique allowed revascularization of the left coronary artery with an average of 3.2 anastomoses per patient without any hospital mortality. The radial artery in this arrangement is starting to be considered as almost an extension of the LITA. Apart from this, this type of revascularization prioritizes the anterior interventricular artery region even in cases of severe radial artery spasms, with the anastomosis of the LITA on this coronary artery. Of the patients who underwent a second examination, one presented with low flow in the radial artery probably due to flow competition. These results support the use of this technique but further evaluation is necessary.

We believe that this technical modification for these composite grafts is simple, safer, more effective and enables a greater number of surgeons to start to routinely utilize composite grafts in coronary artery bypass grafting.

\section{BIBLIOGRAPHIC REFERENCES}

1. Loop FD, Lytle BW, Cosgrove DM, Stewart RW, Goormastic $\mathrm{M}$, Williams GW et al. Influence of the internal mammary artery graft on 10-year survival and other cardiac events. N Engl J Med 1986; 314:1-6.

2. Acinapura AJ, Rose DM, Jacobowitz IJ, Kramer MD, Robertazzi RR, Feldman J et al. Internal mammary artery bypass grafting: influence on recurrent angina and survival in 2100 patients. Ann Thorac Surg 1989; 48:186-91.

3. Fiore AC, Naunheim KS, Dean P, Kaiser GC, Pennington G, Willman VL et al. Results of internal thoracic artery grafting over 15 years: single versus double grafts. Ann Thorac Surg 1990; 49:202-9.

4. Pick AW, Orszulak TA, Anderson BJ, Schaff HV. Single versus bilateral internal mammary artery grafts: 10-year outcome analysis. Ann Thorac Surg 1997; 64:599-605.

5. Sergeant P, Blackstone E, Meyns B. Is return of angina after coronary artery bypass grafting immutable, can it be delayed, and is it important? J Thorac Cardiovasc Surg 1998; 116:440-53.

6. Sergeant PT, Blackstone EH, Meyns BP. Does arterial revascularization decrease the risk of infarction after coronary artery bypass grafting? Ann Thorac Surg 1998; 66:1-11.

7. Lytle BW, Blackstone EH, Loop FD, Houghtaling PL, Arnold $\mathrm{JH}$, Akhrass et al. Two internal thoracic artery grafts are better than one. J Thorac Cardiovac Surg 1999; 117:855-72.

8. Calafiore AM, Di Giammarco G, Luciani N, Maddestra N, Di Nardo E, Angelini R. Composite arterial conduits for a wider arterial myocardial revascularization. Ann Thorac Surg 1994; 58:185-90. 
9. Tector AJ, Amundsen S, Schmahl TM, Kress DC, Peter M. Total revascularization with T grafts. Ann Thorac Surg 1994; 57:33-9.

10. Calafiore AM, Di Giammarco G, Teodori G, D'Annunzio E, Vitolla G, Fino $\mathrm{C}$ et al. Radial artery and inferior epigastric artery in composite grafts: improved midterm angiographic results. Ann Thorac Surg 1995; 60:517-24.

11. Weinschelbaum EE, Gabe ED, Macchia A, Smimmo R, Suarez LD. Total myocardial revascularization with arterial conduits: radial artery combined with internal thoracic arteries. J Thorac Cardiovasc Surg 1997; 114:911-6.

12. Sundt III TM, Barner HB, Camillo CJ, Gay Jr WA. Total arterial revascularization with an internal thoracic artery and radial artery T graft. Ann Thorac Surg 1999; 68:399-405.
13. Aguero OR, Navia JL, Navia JA, Mirtzouian E. A new method of myocardial revascularization with the radial artery. Ann Thorac Surg 1999; 67:1817-8.

14. Markwirth T, Hennen B, Scheller B, Schäfers HJ, Wendler O. Flow wire measurements after complete arterial coronary revascularization with T-grafts. Ann Thorac Surg 2001; 71:788-93.

15. Royse AG, Royse CF, Groves KL, Bus B, Yu G. Blood flow in composite arterial grafts and effect of native coronary flow. Ann Thorac Surg 1999; 68:1619-22. 